\title{
Who in British Columbia is committed to Sustainable Forest Management?
}

History

I ritish Columbia's forest management D has evolved over the last 50 years. In the 1960s the focus was on timber management and sustained yield. In the 1970s environmental concerns began to enter into the decisions by professional foresters, bringing the requirement to evaluate the impact timber management would have on other resources such as fish and wildlife habitats. Environmental Non-Governmental Organizations (ENGOs) began to pressure the forest industry and Government to change $\mathrm{BC}$ forest practices. During this decade, professional foresters had a significant influence on Government and corporate decisions relative to forest lands. Chief Executive Officers and Government Ministers left the forest to the control of Chief Foresters. These individuals were not only influential but provided good forest sector leadership in industry and Government.

In the 1980s the forest industry was subjected to a recession while ENGOs had established a significant position to influence forest management. Major concerns were clearcutting, over-cutting and lack of protected areas. This led to road blocks and the "war in the woods." Throughout this decade professional foresters retained their influence on forest management decisions.

The 1990s saw the establishment of a very prescriptive Forest Practices Code Act (FPC) influenced by ENGOs and designed to provide support for more sensitive and publicly accountable forest management. The decade also brought forward a significant increase in land use planning, identification of protected areas (12\% of BC landbase), biodiversity conservation and consideration of other non-timber resources. ENGOs had successfully brought forest land issues to the offices of the CEOs, the Premier and Government Ministers. The decision-making influence of professional foresters was diminished. Market campaigns were initiated and became very effective and influenced industry customers. Third-party forest certification was born. CEOs and Ministers were making the decisions with Chief Foresters and practising foresters no longer the primary influencers.

Through the first decade of the $21^{\text {st }}$ century the forest industry was subjected to a number of economic challenges, including global competitiveness, the Canada-US Softwood Lumber Agreement and the recession. The focus was on short-term economics. Industry also received a positive response from Government regarding requests to reduce costs. Therefore, the short-term focus displaced Sustainable Forest Management (SFM) as a major priority in decision-making. In addition, the forest management leadership experienced in the 1970-2000 period within industry and Government no longer existed to fight against this direction. The finance people were in control.

Over the last 50 years, both the influence and profile of forest professionals have risen and fallen relative to $\mathrm{BC}$ forest lands decisions. Throughout the challenges, forest professionals remain dedicated to SFM and the public continues to look to them for advice and assurances that public forest lands are being managed to deliver expectations. This high regard is as strong as ever at a time when communities are looking for ways to create diversity and sustainability.

\section{Recent Changes}

The last 10 years have brought a number of changes relative to $\mathrm{BC}$ forest management, in addition to the new Government and industry focus. One of these was the move away from the prescriptive FPC and introduction of a results-based Forest and Range Practices Act (FRPA), which is dependent upon professional reliance rather than detailed prescriptions. This is a sound concept for such a widely diverse province but it has its challenges in implementation and generating public confidence.

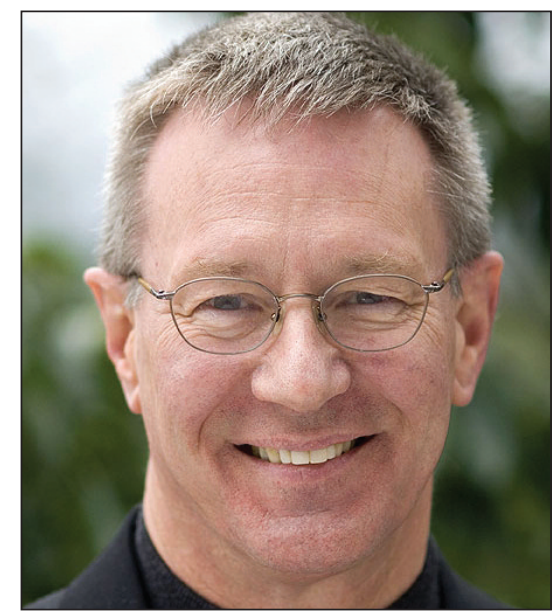

Bill Bourgeois, PhD, RPF President, New Direction Resource Management Ltd.

Economic challenges facing the forest industry since 2000 and the composition of corporate shareholders with expectations for early returns on investments have encouraged companies to become manufacturing-focused with forest resources being a cost associated with the final product. This has caused corporate decision-makers to encourage foresters to reduce log costs and only do what is legally required (i.e., minimum, short-term forest management). Although there are forest professionals planning and doing more than this minimum, these actions will only be approved if they do not have significant impacts on log prices. Consequently, industrial forest professionals are being encouraged to recommend practices and promote legislation, regulations and policies that support the short-term economic needs of the industry and possibly impacting long-term sustainability.

The Government support of the industry direction and the reduction in revenue to provincial coffers has resulted in actions that are viewed by many to have significant impacts on forest management. Examples include: 
- No long-term forest lands vision to guide policy and management decisions

- Regeneration levels at $40 \%-70 \%$ in Mountain Pine Beetle-impacted areas

- Staff reductions of $25 \%$ in 10 years in the BC Forest Service, most in monitoring

- Funding levels reduced to $45 \%$ of the estimated essential staffing levels for inventories maintenance with $75 \%$ of the inventories being 25 years old

- Unprecedented low funding levels for forest research (i.e., $80 \%$ decrease over the last three years)

- Short-term management policies to assist industry while trying to maintain forest stewardship

- Transfer of community (Aboriginal and non-Aboriginal) wildfire interface hazard reduction planning and implementation responsibility from Government to communities with limited funding

- Industry focus on funding market access at the expense of forest management allocations

- Limited activity level of public involvement in strategic land and resource planning

- Little coordination and timber impact limits associated with non-traditional forest resources management

- Low funding allocations for marketing of "value-added products" (10\%-25\% of total Government marketing funds) to encourage higher return from the forest fibre

- Funding levels (\$1 M/year for each Beetle Action Coalition for three years) for community diversification in MPB-impacted areas; hundreds of millions are required

- Failure to remove policy barriers to encourage wood utilization for bioenergy

- Lack of biodiversity protection initiatives leaving BC biodiversity “... vulnerable to rapid deterioration, especially in light of climate change,"

- Limited adaptation response to global environmental influences such as climate change

- Limited action regarding cumulative impacts on forest lands

- Limited habitat restoration in areas impacted by the MPB epidemic

- Limited action on the impacts of MPB harvesting on streamflows

- Low levels of meaningful community participation
These examples send a message that there is inadequate staffing, policies and instruments required to practise and demonstrate the practice of SFM. More detail on these can be found in Will BC forests deliver - A forester's challenge posted in the "What's New" section of the Healthy Forests-Healthy Communities Web site (http://bcforestconver sation.com).

\section{Future Leadership}

The 1980s recession resulted in major changes to the way forest management was conducted. Staff levels were reduced with company crews being replaced with contractors and staff activities not directly related to log production eliminated. Corporate staffing levels never rebounded and foresters got used to doing more with less. Forest professionals are an innovative and resilient bunch! The recent recession has further changed the way the forest industry operates. There is more emphasis on minimizing costs, reducing non-essential activities and performing to the minimum legal requirements in the forest. There has been a further erosion of funding and staffing for forest management, both in industry and Government. The results are viewed by many as a move away from SFM. Just as in the case of the 1980s recession, recent changes are not expected to go back to what was done in the 1990s. Corporate customers and the public continue to demand SFM. Therefore, foresters will be asked again to do more with less and to find innovative ways to practise and demonstrate SFM.

Concerns over the direction of $\mathrm{BC}$ forest management worried a number of professional foresters and biologists, conservationists, academics, community leaders, forest support companies and First Nations over the last two years. This generated the Healthy Forests Healthy Communities: A conversation on $B C$ forests (HFHC, http://bcforestconversation.com) early in 2011. It is a non-partisan, volunteer-supported initiative to both catalyze dialogue with natural resource experts and local communities to inform decision-makers regarding the people's vision for BC forest lands and to identify areas for improving long-term sustainable management. The interim results identified:

- If forest management is to deliver on a forest lands vision, 12 key challenges face BC professionals and decision-makers based on the comments from $37 \mathrm{BC}$ forest management leaders; and

- Communities are concerned about the future of their forests and want more say in the decisions, more information regarding the status of the forest and require decision-makers to take forest management actions that will contribute to a viable and sustainable local forest industry.

The current lack of leadership within industry and Government regarding BC forest management will limit the possibility of fighting their current direction. Major ENGOs, although sharing the concerns over the future of $\mathrm{BC}$ forest lands, are focusing on global issues such as climate change. Forest professionals in Government, industry and the consulting sector are constrained in publicly advocating, as individuals, change to current practices and policies, supported by their employers or clients. Who should take on the leadership on this issue? Communities and forest professional organizations have the public mandate, if they choose to use it. To date, the Association of $\mathrm{BC}$ Forest Professionals (ABCFP) has focused its limited advocacy on behind-closed-door meetings with Government and the occasional article in the newspaper, the most recent supporting current forest management. Personally, this type of action to avoid risking alienation of industry or Government is not doing a service to its members or the public. The Canadian Institute of Forestry/Institut forestier du Canada (CIF/IFC), National and $\mathrm{BC}$ Sections, has recently taken action to be the primary partner in the HFHC initiative. This was a welcomed leadership role. Communities (Aboriginal and non-Aboriginal) are limited in capacity (funding and expertise) but clearly want to be involved. However, they want the advice of forest professionals.

The forest industry and Government direction, the financial situation, reduced staffing levels of forest professionals, the challenges identified by the $\mathrm{BC}$ forest management leaders and the expectations of communities require the profession and their members to take unprecedented steps to raise the profile of forest management in the eyes of decision-makers. There is an opportunity for the CIF/IFC and/or ABCFP to take a leadership role, with support from 
academics, communities and First Nations. However, this must involve a willingness to be outspoken advocates with messages supported by science, documentation and passion. Forest professionals are the only viable and com- mitted group to take on this critical challenge. Will the CIF/IFC and/or ABCFP step up and partner with communities and academics to ensure the BC forest lands deliver on the public expectations over the long-term? I look forward to the dialogue on this over the next few months.

Bill Bourgeois, $\mathrm{PhD}, \mathrm{RPF}$

President, New Direction Resource Management Ltd

\section{Qui soutient l'aménagement forestier durable en Colombie-Britannique?}

\section{Contexte}

'aménagement forestier en ColombieBritannique a évolué au cours des 50 dernières années. Dans les années 60, laménagement de la matière ligneuse et le rendement soutenu étaient au cœur des préoccupations. Au cours des années 70, les enjeux environnementaux ont commencé à être pris en considération par les forestiers professionnels, entraînant l'obligation d'évaluer l'impact de l'aménagement de la matière ligneuse sur les autres ressources comme les habitats aquatiques et fauniques.

Les organisations non gouvernementales environnementales (ONGE) ont commencé à exercer des pressions sur l'industrie forestière et le gouvernement pour que soient modifiées les pratiques forestières utilisées en C.-B. Au cours de cette décennie, les forestiers professionnels ont exercé une influence prépondérante au niveau des décisions du gouvernement et des entreprises reliées aux terres forestières. Les directeurs généraux et les ministres avaient laissé les forêts sous le contrôle des forestiers en chef. Ces individus n'exerçaient pas seulement de l'influence mais également un leadership adéquat au sein de l'industrie et du gouvernement pour le secteur forestier.

Dans les années 80, l'industrie forestière a connu une récession et les ONGE ont occupé une position déterminante pour influencer l'aménagement forestier. Les principales inquiétudes portaient sur la coupe à blanc, la surcoupe et le manque de surfaces protégées. Ces problèmes provoquèrent des barrages routiers et amorcèrent " la guerre des forêts ». Tout au long de cette décennie, les forestiers professionnels réussirent à maintenir leur influence sur les décisions touchant l'aménagement forestier.

Les années 90 furent celles de la mise en place d'une loi très détaillée créant le
Code de pratiques forestières (CPF) sous l'influence marquée des ONGE et conçu pour permettre la mise en place d'un aménagement forestier plus spécifique et plus imputable aux yeux des intervenants. La décennie a vu également une hausse significative de la planification de l'utilisation du territoire, de l'identification des zones à protéger (12\% des terres de la province), de la conservation de la biodiversité et de l'attention portée aux autres ressources non ligneuses. Les ONGE ont réussi à défendre avec succès les enjeux touchant le territoire forestier dans les bureaux des dirigeants d'entreprise, du Premier ministre et des ministres du gouvernement. L'influence sur la prise de décision détenue par les forestiers professionnels en a été réduite. Des campagnes de promotion ont été lancées et furent très efficaces pour influencer les acheteurs industriels. La certification indépendante vit le jour. Les directeurs généraux d'entreprise et les ministres ont pris dorénavant les décisions en collaboration avec les forestiers en chef et les forestiers professionnels n'avaient plus d'influence déterminante.

Au cours de la première décennie du $\mathrm{XXI}^{\mathrm{e}}$ siècle, l'industrie forestière a fait face à plusieurs défis, dont sa compétitivité sur les marchés mondiaux, le litige entre le Canada et les États-Unis sur le bois d'œuvre et la récession. Lattention portait sur les mesures économiques à court terme. L'industrie a reçu également une réponse positive de la part du gouvernement relativement à ses requêtes de réduction des coûts. En conséquence, les besoins à court terme ont remplacé l'aménagement forestier durable (AFD) au sommet des priorités. De plus, le leadership exercé en aménagement forestier au cours de la période de 1970 à 2000 par l'industrie et le gou- vernement nétait plus en mesure de combattre cette tendance. Les financiers étaient aux commandes.

Au cours des 50 dernières années, autant l'influence que l'image des forestiers professionnels ont été prépondérantes puis négligeables dans les décisions touchant le territoire forestier de la C.-B. Tout au long de ces défis, les forestiers professionnels ont maintenu leur appui à l'AFD et le public a continué de se tourner vers eux pour obtenir des conseils et l'assurance que les terres forestières publiques étaient aménagées de façon à respecter leurs attentes. Cette haute considération est aussi forte que jamais alors que les communautés cherchent des moyens de créer de la diversité et de la durabilité.

\section{Changements récents}

Les dix dernières années ont apporté de nombreuses modifications de l'aménagement forestier en C.-B., en plus de la nouvelle orientation suivie par le gouvernement et l'industrie. Parmi celles$\mathrm{ci}$, on retrouve l'abandon des prescriptions retrouvées dans le CPF et l'introduction de la Loi sur les pratiques forestières et la faune (LPFF) découlant des résultats et reposant sur une évaluation professionnelle plutôt que sur des prescriptions détaillées. Il s'agit d'un concept valable pour une province aussi diversifiée que la nôtre, mais qui présente des défis au niveau de son implantation et de son approbation par le public.

Les perturbations économiques subies par l'industrie forestière depuis 2000 et le genre d'actionnaires retrouvé dans les entreprises qui visent des retours sur l'investissement rapides, ont encouragé les compagnies à se concentrer sur la transformation et à considérer les ressources forestières comme un coût associé au produit fini. Cela a eu 
pour effet que les décideurs au sein des entreprises ont encouragé les forestiers à réduire les coûts associés à la matière ligneuse et à ne faire que ce qui était requis par la loi (cest-à-dire, que de laménagement forestier à court terme et le minimum requis). Même s'il y a des forestiers professionnels qui planifient et font plus que le minimum requis, il demeure que ces gestes ne seront approuvés que s'ils ont un effet significatif sur le prix de la matière ligneuse. En conséquence, les forestiers professionnels de l'industrie sont encouragés à recommander des pratiques et à promouvoir des lois, des règlements et des politiques qui saccordent aux besoins économiques à court terme de l'industrie et qui ont probablement un impact à long terme sur la durabilité.

Le gouvernement appuie lorientation de lindustrie et la réduction des revenus versés dans les coffres de l'État a entrâné des conséquences perçues par plusieurs personnes comme ayant des effets significatifs sur l'aménagement forestier. À titre dexemples :

- Labsence de vision à long terme du territoire forestier permettant de guider les décisions touchant les politiques et l'aménagement

- Des niveaux de régénération fixés de $40 \%$ à $70 \%$ dans les zones touchées par le dendroctone du pin

- Des réductions d'effectif de $25 \%$ en 10 ans au sein du Service forestier de la C.-B., en grande partie au niveau du suivi

- Des coupures de financement de $45 \%$ dans les effectifs estimés comme étant essentiels à la mise à jour des inventaires dont $75 \%$ ont plus de 25 ans

- Le financement de la recherche forestière à un niveau minimal sans précédent (une diminution de $80 \%$ au cours des trois dernières années)

- Des politiques d’aménagement à court terme pour aider l'industrie tout en essayant de maintenir l'intendance des forêts

- Le transfert des responsabilités portant sur la planification et l'implantation de mesures de réduction des risques d'incendies de forêt hors contrôle affectant les communautés (autochtones et non-autochtones), du gouvernement aux communautés avec des budgets réduits

- Lorientation de l'industrie sur le financement de l'accessibilité des marchés au détriment des investissements en aménagement forestier

- Le peu d'incitation exercée pour obtenir la participation du public au niveau de la planification stratégique du territoire et des ressources

- Le peu de coordination et de mesures d'atténuation de lexploitation de la matière ligneuse dans le cas de laménagement des ressources forestières non traditionnelles

- Le faible niveau de financement pour la mise en marché de " produits à valeur ajoutée " $(10 \%-25 \%$ de tous les fonds de promotion du gouvernement) permettant dobtenir un rendement plus élevé de l'utilisation des fibres forestières

- Le financement (1 $\mathrm{M} \$ /$ an pour chaque groupe daction et pour trois ans) de projets de diversification pour les communautés affectées dans les zones touchées par le dendroctone du pin; des centaines de millions de dollars sont requis

- Le non retrait des obstacles légaux empêchant l'utilisation de la matière ligneuse à des fins bioénergétiques

- Labsence de mesures de protection de la biodiversité faisant en sorte que cette dernière en C.-B. « ... est susceptible de se détériorer rapidement, spécialement à la suite des changements climatiques, »

- Les mesures limitées d'adaptation face aux perturbations environnementales planétaires comme les changements climatiques

- Le peu de gestes concrets portant sur les effets cumulatifs répertoriés sur le territoire forestier

- Le faible niveau de restauration des habitats dans les zones affectées par lépidémie du dendroctone du pin

- Le peu de mesures posées pour atténuer les impacts de la récolte de bois ravagé par le dendroctone du pin sur le débit des cours d'eau

- Le faible niveau de participation significative de la part des communautés

Ces exemples indiquent clairement qu'il y a un manque deffectif, de règlementation et de moyens permettant de pratiquer et de démontrer la pratique de l'AFD. De plus amples détails peuvent être consultés sous la rubrique Will $B C$ forests deliver - A forester's challenge affichée dans la section «What's New » du site internet Healthy Forests-Healthy Communities (http://bcforestconversation.com).

\section{Leadership envisagé :}

La récession de 1980 a entraîné des changements importants dans la façon de faire l'aménagement forestier. Des réductions de personnel ont eu lieu suite au remplacement des équipes d’entreprises par des entrepreneurs et les activités du personnel non rattachées à la production de bois ont été éliminées. Les effectifs au sein des entreprises nont jamais reaugmenté et les forestiers se sont habitués à faire plus avec moins. Les forestiers professionnels sont des gens capables d'innovation et de résilience! La récente récession a modifié encore plus la façon d'opérer de l'industrie forestière. Laccent est mis sur la réduction des coûts, la réduction des activités non essentielles et la réalisation des travaux forestiers requis pour répondre aux exigences minimales. Il ya eu une érosion accélérée du financement et de la dotation en personnel rattachés à l'aménagement forestier, tant au sein de l'industrie que du gouvernement. Les résultats sont perçus par plusieurs personnes comme étant un abandon de l'AFD. Comme cela a été le cas pour la récession des années 80 , les récents changements ne sont pas considérés comme permettant un retour à ce qui se faisait dans les années 90. Les acheteurs industriels et le public exigent le maintien de l'AFD. En conséquence, les forestiers devront encore une fois faire plus avec moins et trouver des moyens innovateurs permettant de pratiquer et de démontrer la pratique de l'AFD.

Plusieurs questions sur lorientation de l'aménagement forestier en C.-B. ont soulevé de linquiétude chez de nombreux forestiers et biologistes professionnels, parmi les défenseurs de l'environnement, les universitaires, les leaders des communautés, les entreprises liées au milieu forestier et les Premières Nations, au cours des deux dernières années. Cet état des choses a généré le texte Healthy Forests - Healthy Communities: A conversation on $B C$ forests (HFHC, http://bcforestconversation.com) publié au début de 2011. Il s'agit d'une initiative indépendante, entreprise par des bénévoles afin de catalyser le dialogue avancé par les 